\title{
ANALYZING THE EFFECT OF MASS IRREGULARITY AND FLOATING COLUMN ON HIGH-RISE STEEL FRAMED STRUCTURE WITH WIND ANALYSIS
}

\author{
ABHISHEK PUNDIR ${ }^{1} \&$ ER.VIKAS ${ }^{2}$ \\ ${ }^{1}$ Structural Engineering, Department of Civil Engineering, Chandigarh University, Punjab, India \\ ${ }^{2}$ Assistant Professor, Department of Civil Engineering, Chandigarh University, Punjab, India
}

\begin{abstract}
The analysis and design of the structures have become a difficult task now days due to presence of different kinds of irregularities in it. To make this as a simple task, the evaluation of performance of these structures is carried out in the professional analysis and designing tool such as Bentley's Staad. Pro, e-tabs, SAP etc. Out of all the irregularities of structures, Mass irregularities and elevation irregularities (having floating column) have become the most common one. Therefore, in present study, 15 and 20 Storey buildings were adopted while introducing floating columns at the upper floors and Mass irregularity at different floor throughout its height. Various vertical loads were taken from the IS codes and along with it, wind forces were applied on the structures. From the results, it has been concluded that the forces and moments increases when the heavy mass is introduced, but if the heavy mass is placed in the upper storeys, the forces and moments becomes higher than that of a building having heavy mass in the lower floors. Displacement of the column decreases as heavy mass increases the lateral capacity of the structure by giving the addition stability due to increase in total vertical load.

KEYWORDS: Extension of Building, RCC Frame Building, Staad. Pro
\end{abstract}

Received: Jun 08, 2020; Accepted: Jun 28, 2020; Published: Sep 16, 2020; Paper Id.: IJMPERDJUN20201264

\section{INTRODUCTION}

It is important to evaluate the complex structures subjected to strong lateral forces as being the developing nation, more and more complex structures with numerous storeys are being built in India. This is due to the advancement in design and construction technologies, architectural appearance and increasing population. One of the main processes in all this is analysis and design of structures and their structural members. On the basis of previous research works by eminent researchers, some standards were published which provides basic and professional guidelines for construction and design. Every situation was depicted by the researchers and numbers of investigational studies were carried out so that the behavior of the structure and its component can be observed.

Steel structure, as shown in figure 1, plays an impeccable part in modern infrastructures as it entails less self-weight than RCC structures and requires less time to erect. But due to its less self-weight, the lateral stability of the structure is compromised and special care is to be taken while designing such structures having large number of storeys. Various cross-sectional conventional shapes of steel (like T-Shape, I-shape, C-Shape, L-Shape etc) and modern shapes (like tubular hollow sections) are connected together in the form of columns and beams with different connecting methods so that members act as a monolithic unit. The design of such building is to be taken as per the IS 800:1984- "For steel structures". 


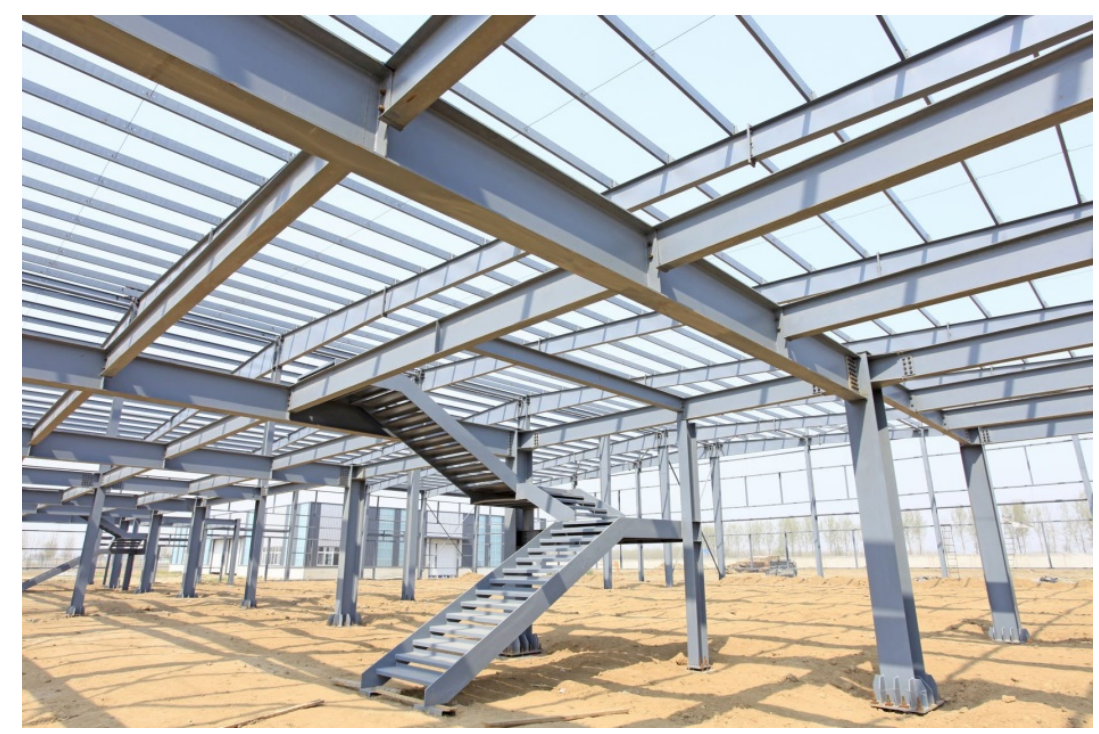

Figure 1: Steel Structure.

Irregularity in a structure simply means that the structure is not symmetrical at its principle axis. Various kinds of irregularities can be introduced in the structure such as vertical irregularity, plan irregularity or both. Most common types of irregularity in high rise structures are is the mass irregularity and irregularity in elevation. Floating column is a column which rests on beams and not on column. See figure 2.

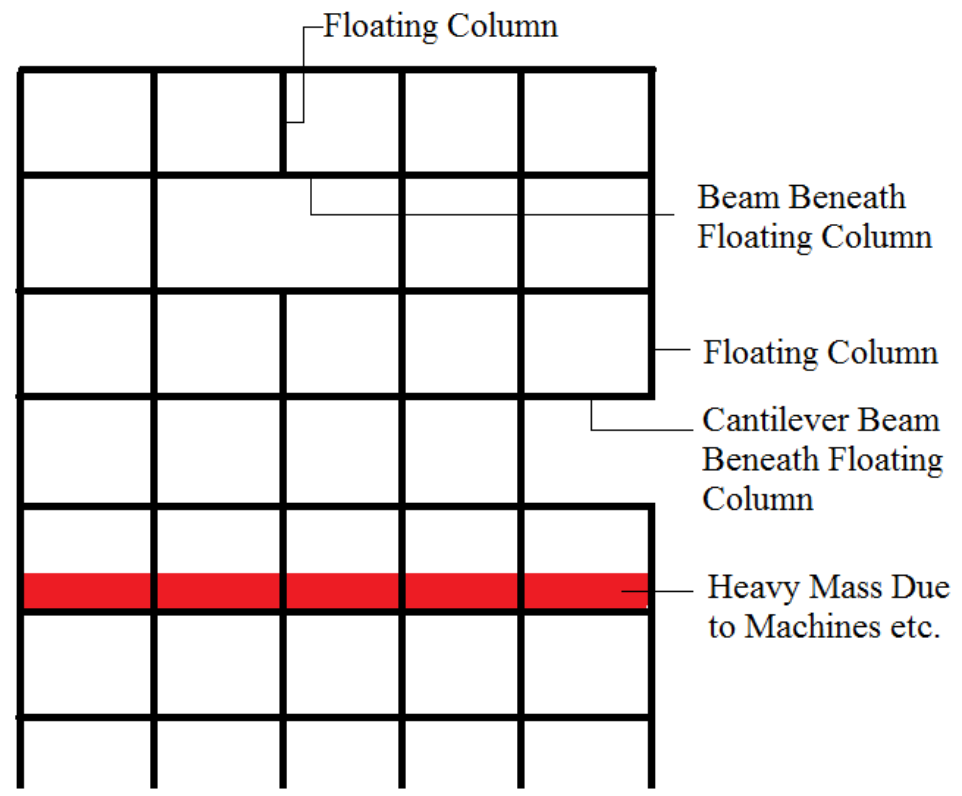

Figure 2: Structure having Mass Irregularity and Floating Column.

\section{RESEARCH METHODOLOGY}

\section{Geometry of Steel Framed Structure \& Introduction of Mass Irregularity and Floating Column}

Various models were modeled using staad.pro software with having different building heights with and without heavy mass entailing floating column. 
Specifications of the model are as under:

- $\quad$ Each structure had 6 bays.

- $\quad$ Each bay was $6 \mathrm{~m}$ x $6 \mathrm{~m}$ in size.

- $\quad$ Each storey was $3.3 \mathrm{~m}$ in height.

- For steel sections, both (conventional and tubular) sections were chosen, whichever is suitable.

- All the models were regular and symmetrical in shape.

Table 1 show the various types of models which were generated under present study.

Table 1: Description of Various Models

\begin{tabular}{|c|c|c|}
\hline Structural Type & Description & Mass Irregularity \\
\hline Type 1 & 15Storey Building With Floating Columns (FC) & None \\
\hline Type 2 & 15Storey Building With Floating Columns (FC) & On $2^{\text {nd }}$ Floor \\
\hline Type 3 & 15 Storey Building With Floating Columns (FC) & On $7^{\text {th }}$ Floor \\
\hline Type 4 & 15 Storey Building With Floating Columns (FC) & On $13^{\text {th }}$ Floor \\
\hline Type 5 & 20Storey Building With Floating Columns (FC) & None \\
\hline Type 6 & 20 Storey Building With Floating Columns (FC) & On $4^{\text {th }}$ Floor \\
\hline Type 7 & 20 Storey Building With Floating Columns (FC) & On $10^{\text {th }}$ Floor \\
\hline Type 8 & 20 Storey Building With Floating Columns (FC) & On $16^{\text {th }}$ Floor \\
\hline
\end{tabular}

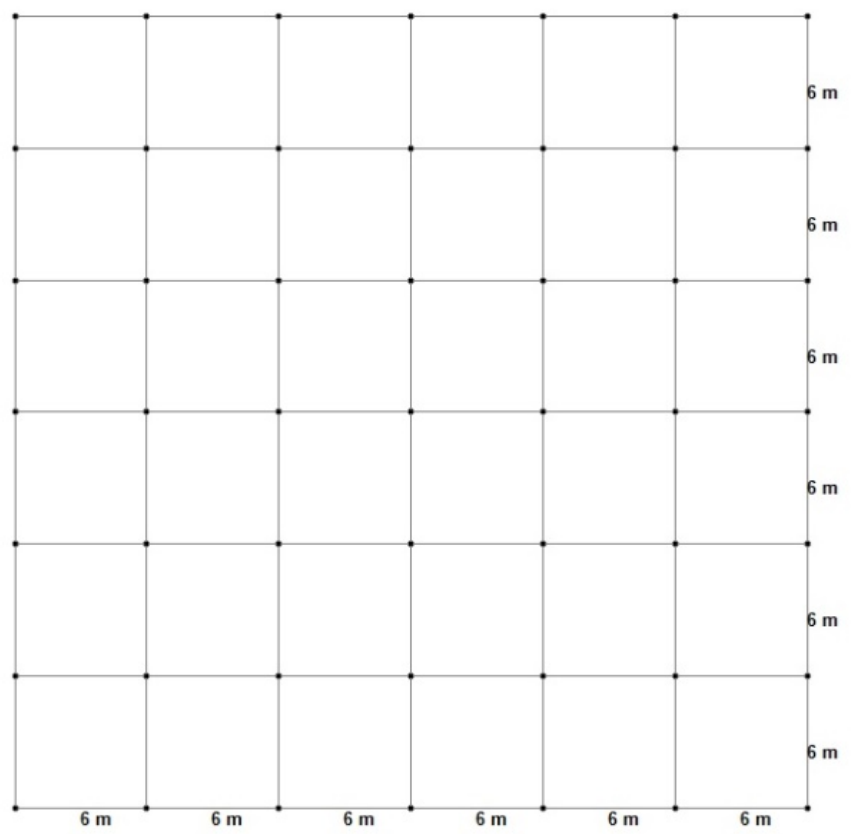

Figure 3: Plan of Structure. 

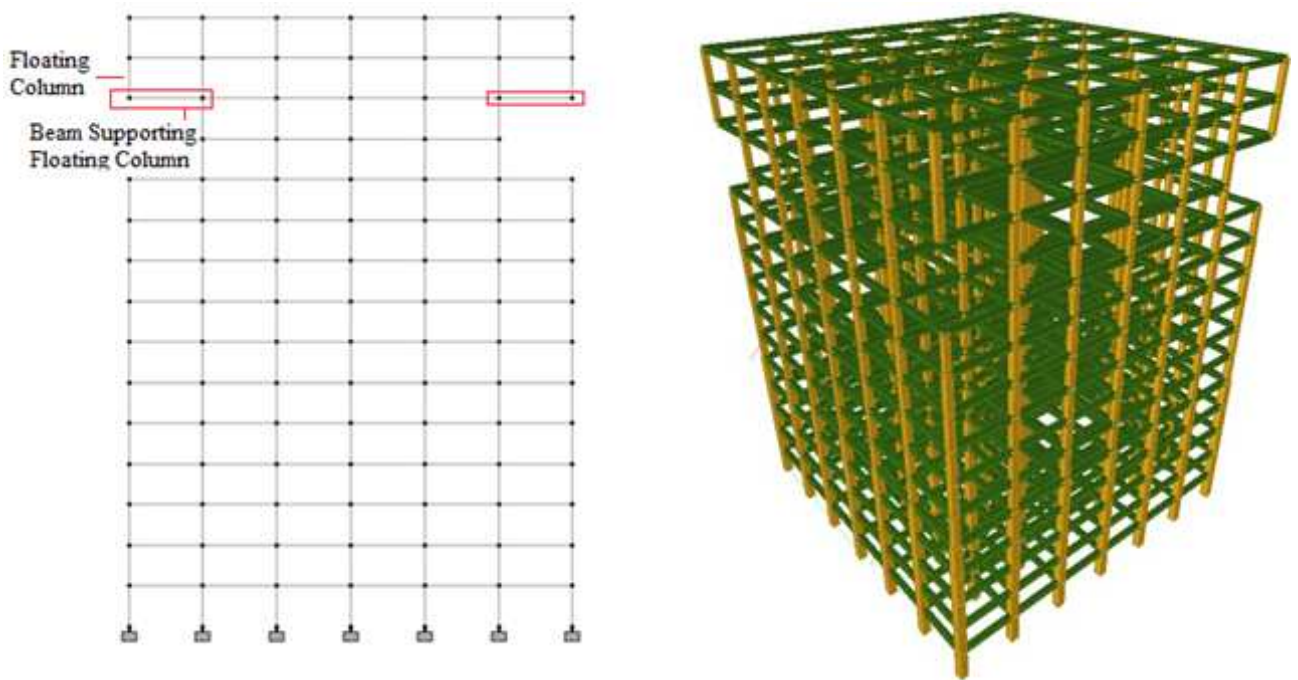

Figure 4: Elevation \& Rendered View of 15 Storey Building with Floating Columns at $14^{\text {th }}$ Floor.
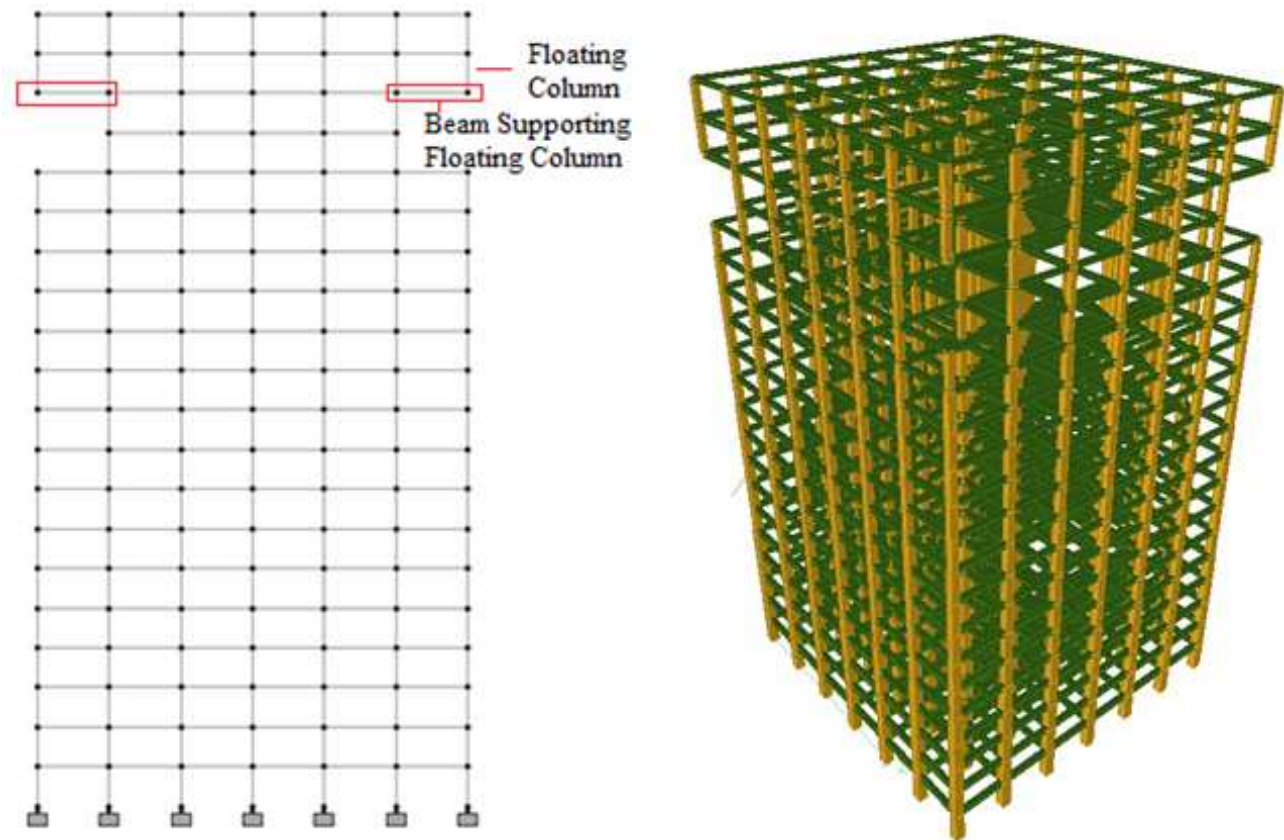

Figure 5: Elevation \& Rendered View of 20 Storey Building with Floating Columns at $19^{\text {th }}$ Floor.

Wind Analysis as per IS: 875 (Part 3)

The behavior of wind in steel structures is very crucial due to its less self-weight and its analysis plays an impeccable role in designing the steel framed structures. Therefore, for the present study, wind analysis was carried out and various parameters of wind were considered for the analysis as per the codal specification of IS: 875 (Part 3).

Table: 2: Input Parameters for Wind Analysis

\begin{tabular}{|l|c|}
\hline \multicolumn{1}{|c|}{ Parameter } & Value \\
\hline Basic Wind speed & $47 \mathrm{~m} / \mathrm{sec}$ \\
\hline $\mathrm{k} 1$, Probability factor & 1 \\
\hline $\mathrm{k} 2$, Terrain, height and structure size factor & 1 \\
\hline $\mathrm{k}$ 3, Topography factor & 1 \\
\hline Therefore, Design Wind Speed $\left(\mathrm{V}_{\mathrm{z}}\right)$ & $47 \mathrm{~m} / \mathrm{sec}$ \\
\hline Wind Pressure $\left(\mathrm{P}=0.6 \mathrm{~V}_{\mathrm{z}}^{2}\right)$ & $1325 \mathrm{~N} / \mathrm{m}^{2}=1500 \mathrm{~N} / \mathrm{m}^{2}$ \\
\hline
\end{tabular}


The wind pressure of $1.5 \mathrm{kN} / \mathrm{m}^{2}$ was calculated as above and applied directly on columns as uniformly distributed load (UDL) as mentioned in figures below. The wind was applied from different directions (i.e. from ' $\mathrm{X}$ ' direction, from '$\mathrm{X}$ ' direction, from ' $\mathrm{Z}$ ' direction and from '-Z' direction) in order to generate different load cases. In this case, the behavior of column was carefully observed and difference was noted. The deflection of column in case of wind along with the mass irregularity was determined as this is the ultimate aim of the study.

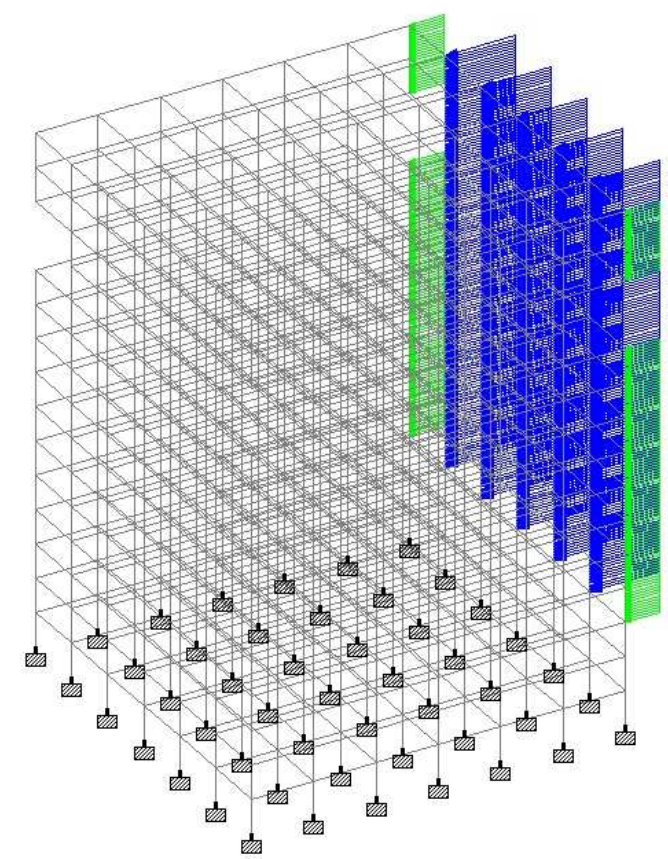

Figure 6: Wind Load Acting as UDL on Columns of 15 Storey Building.

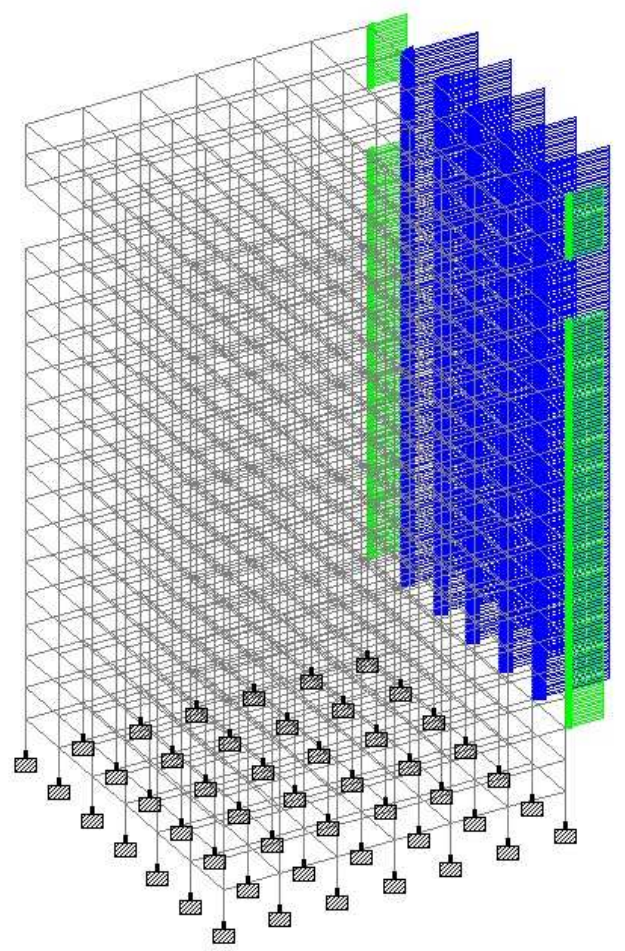

Figure 7: Wind Load Acting as UDL on Columns of 20 Storey Building. 


\section{RESULTS OF 15 STOREY BUILDING}

The results of various parameters have been represented below:

The maximum bending moment in the $2^{\text {nd }}$ floor beams with and without heavy mass was recorded as $204.365 \mathrm{kN}$ $\mathrm{m}$ and $172.084 \mathrm{kN}-\mathrm{m}$ respectively. But if the same mass is shifted to $7^{\text {th }}$ floor of the building, then the maximum bending moment in $7^{\text {th }}$ floor beams with and without the heavy mass becomes $258.338 \mathrm{kN}-\mathrm{m}$ and $225.663 \mathrm{kN}-\mathrm{m}$ respectively. Again after shifting the heavy mass onto the $13^{\text {th }}$ floor, the value of maximum bending moment in $13^{\text {th }}$ floor beams with and without the heavy mass comes out to be $191.386 \mathrm{kN}-\mathrm{m}$ and $152.218 \mathrm{kN}-\mathrm{m}$ respectively. Therefore, from the figures 8 , 9 and 10,it was concluded that when the heavy mass was placed at $2^{\text {nd }}$ floor, the value of bending moment increases approximately $26 \%$ whereas, when the heavy mass is shifted to $7^{\text {th }}$ floor, the increase in bending moment was found out to be $31 \%$. And if the heavy mass is placed at $13^{\text {th }}$ floor, then the approximate increase in bending moment comes out to be $36 \%$.

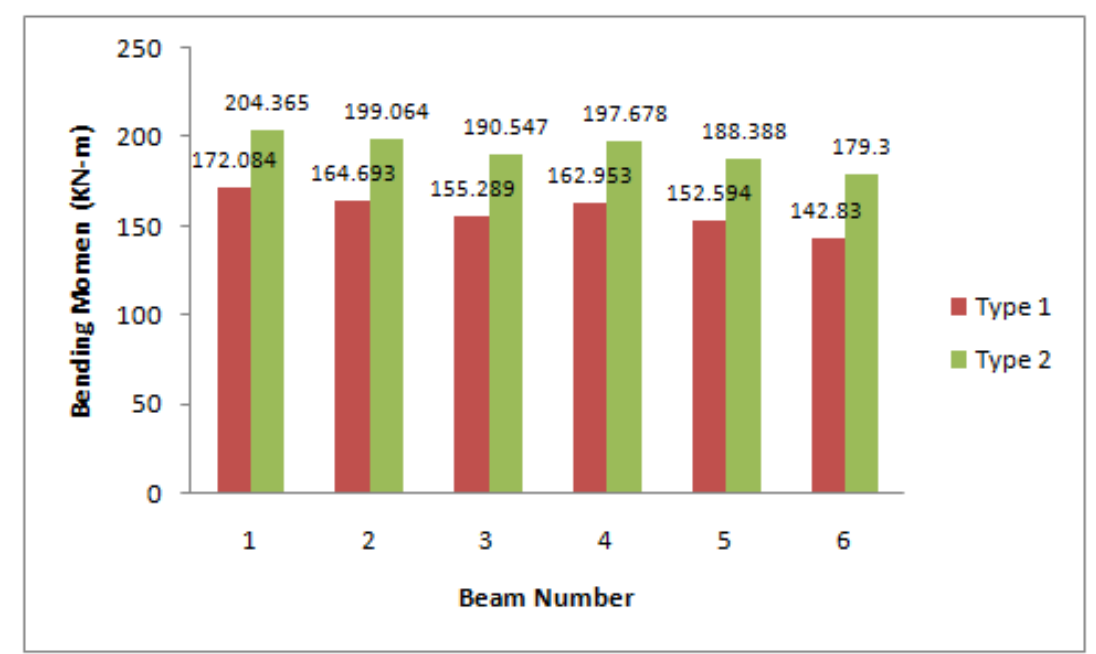

Figure 8: Bending Moment of $2^{\text {nd }}$ Floor Beam with and without Heavy Mass of 15 Storey Building.

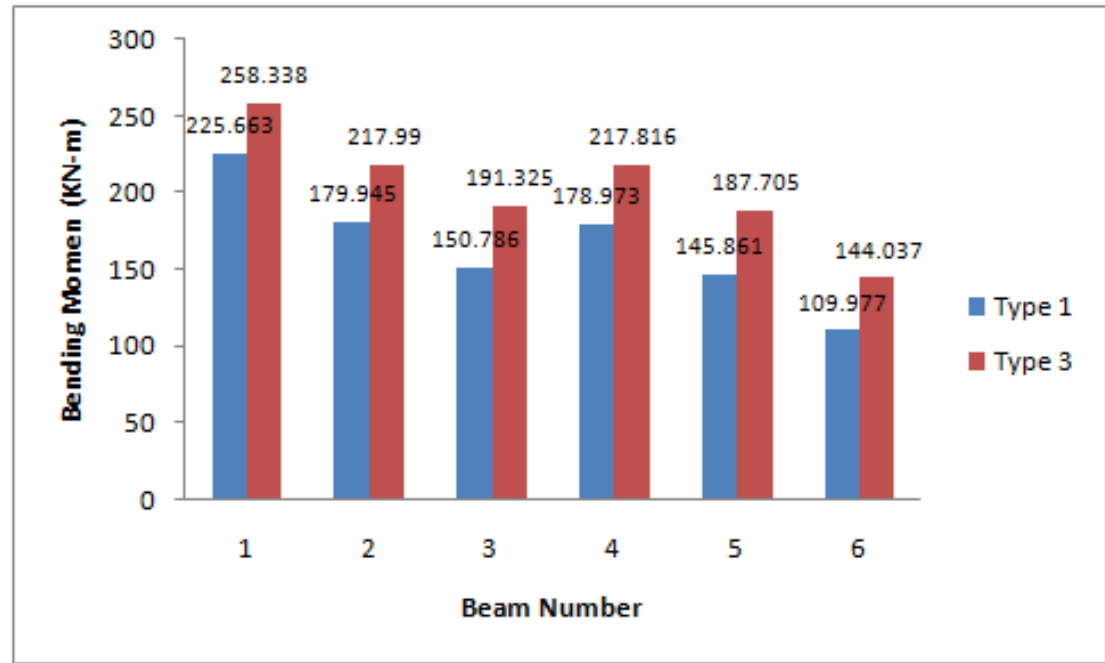

Figure 9: Bending Moment of $7^{\text {th }}$ Floor Beam with and without Heavy Mass of 15 Storey Building. 


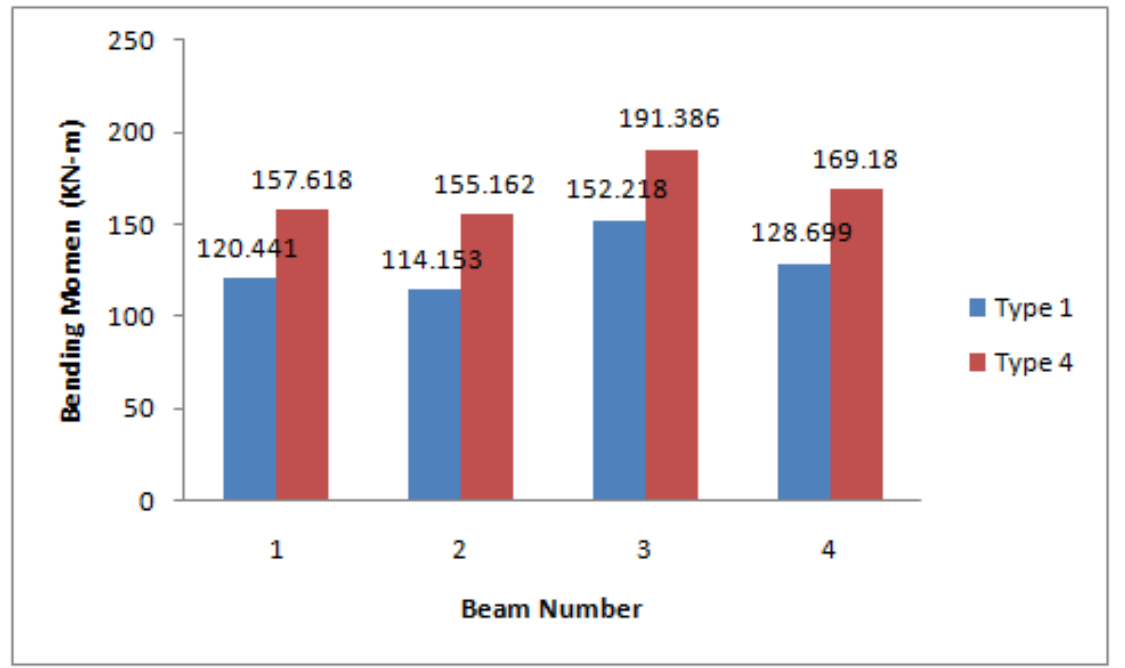

Figure 10: Bending Moment of $13^{\text {th }}$ Floor Beam with and without Heavy Mass of 15 Storey Building.

The maximum shear force in the $2^{\text {nd }}$ floor beams with and without heavy mass was recorded as $148.444 \mathrm{kN}$ and $118.639 \mathrm{kN}$ respectively. But if the same mass is shifted to $7^{\text {th }}$ floor of the building, then the maximum shear force in $7^{\text {th }}$ floor beams with and without the heavy mass becomes $165.759 \mathrm{kN}$ and $135.653 \mathrm{kN}$ respectively. Again after shifting the heavy mass onto the $13^{\text {th }}$ floor, the value of maximum shear force in $13^{\text {th }}$ floor beams with and without the heavy mass comes out to be $142.705 \mathrm{kN}$ and $110.693 \mathrm{kN}$ respectively. Therefore, from the figures 11,12 and 13 , it was concluded that when the heavy mass was placed at $2^{\text {nd }}$ floor, the value of shear force increases approximately $29 \%$ whereas, when the heavy mass is shifted to $7^{\text {th }}$ floor, the increase in shear force was found out to be $31 \%$. And if the heavy mass is placed at $13^{\text {th }}$ floor, then the approximate increase in shear force comes out to be $34 \%$.

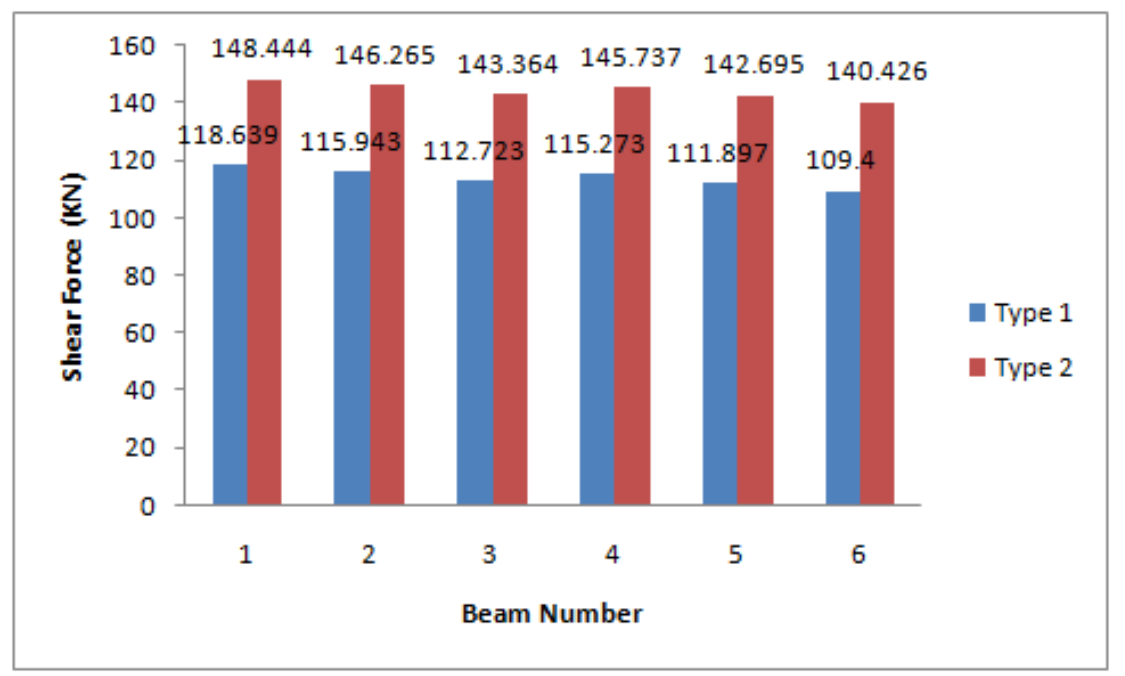

Figure 11: Shear Force of $2^{\text {nd }}$ Floor Beam with and without Heavy Mass of 15 Storey Building. 


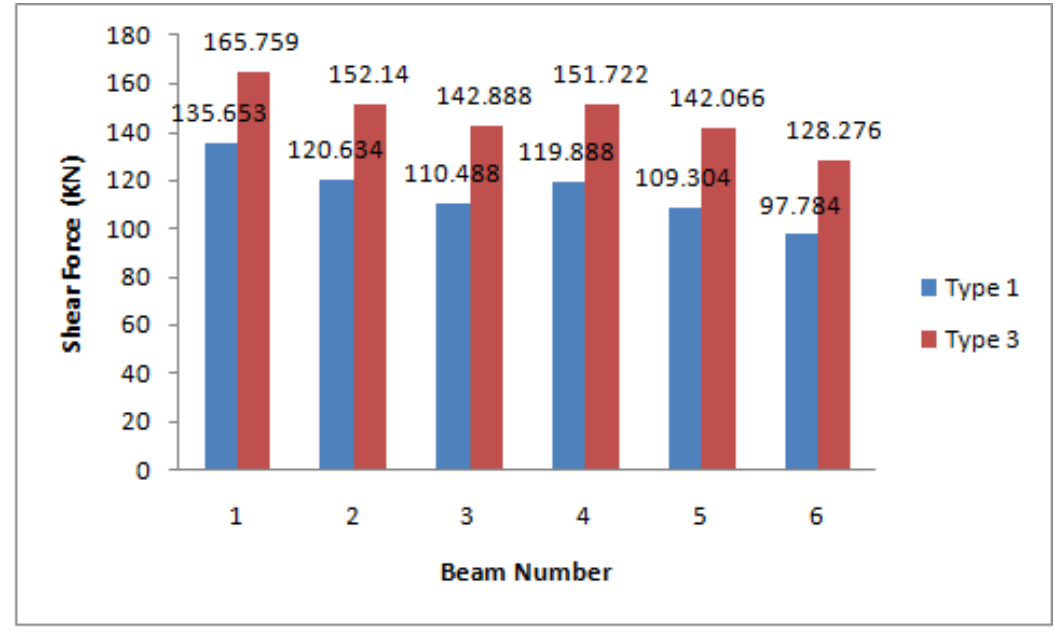

Figure 12: Shear Force of $7^{\text {th }}$ Floor Beam with and without Heavy Mass of 15 Storey Building.

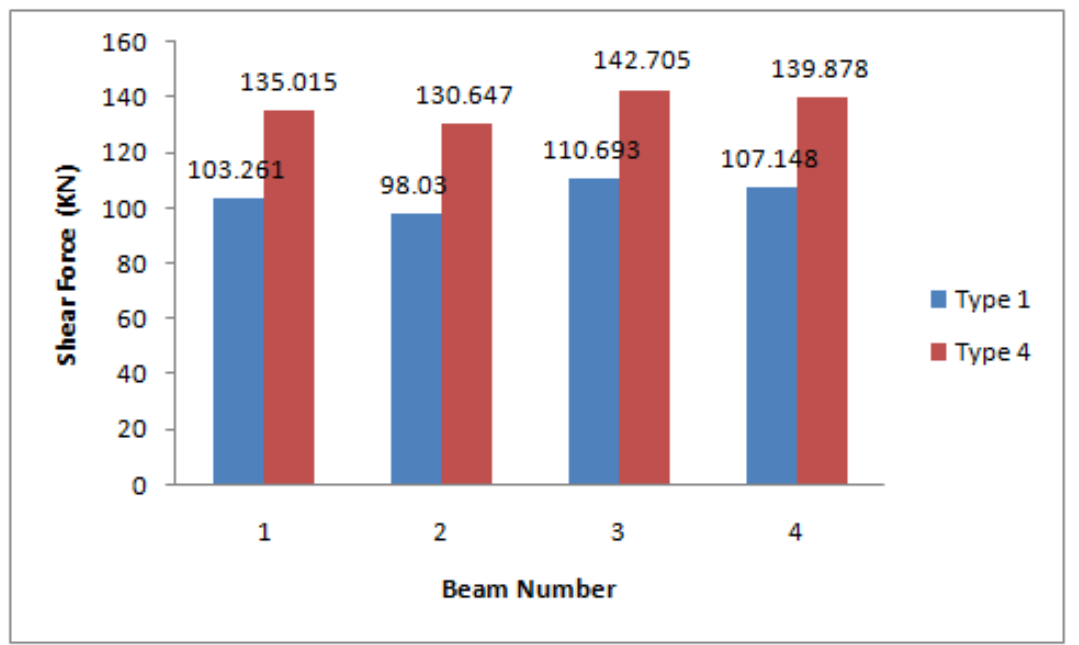

Figure 13: Shear Force of $13^{\text {th }}$ Floor Beam with and without Heavy Mass of 15 Storey Building.

As the beam beneath the floating column act as a cantilever beam, the bending moment and shear force value comes out to be huge. Maximum bending moment and shear force value comes out to be $454 \mathrm{kN}-\mathrm{m}$ and $207 \mathrm{kN}$ repectively as shown in figure 14 and 15.

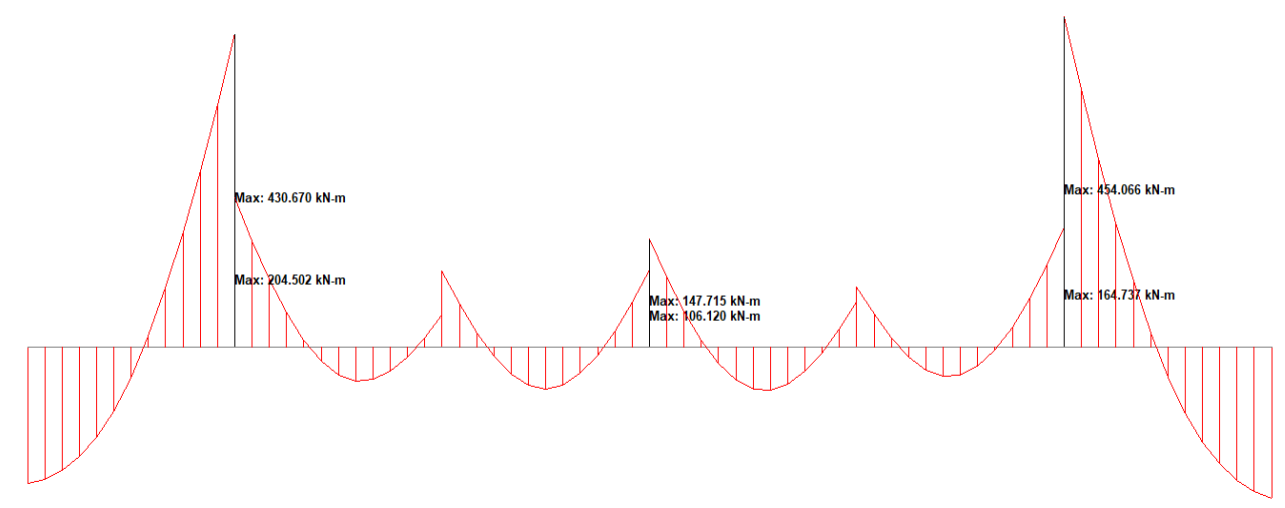

Figure 14: Bending Moment of End Beams where Floating Columns are Placed. 


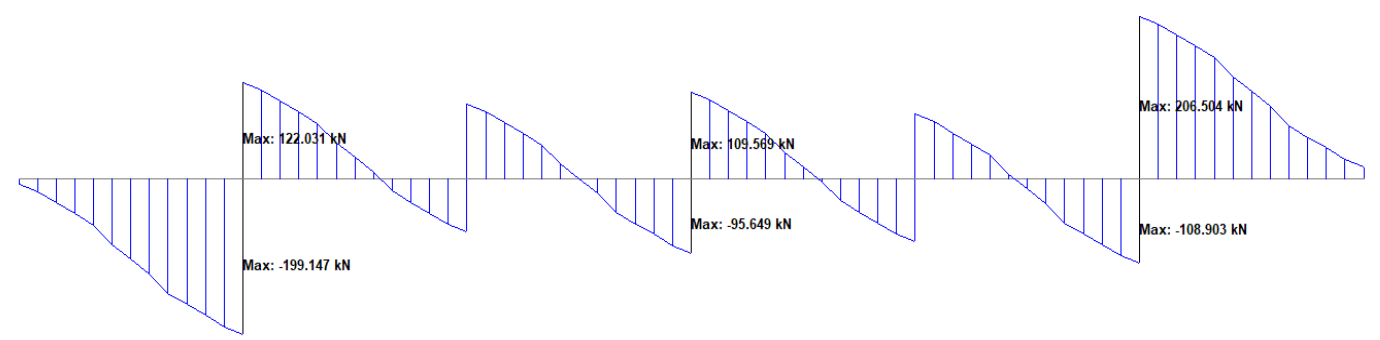

Figure 15: Shear Force of End Beams where Floating Columns are Placed.

Due to increase in the total weight of the building (having heavy mass) which increases the lateral stability, the displacement of the columns decreases. Maximum decrease in the column displacement was calculated as $4 \%, 6 \%$ and $7 \%$ approximately when the heavy mass was placed at $2^{\text {nd }}$ floor, $7^{\text {th }}$ floor and $13^{\text {th }}$ floor respectively when compared to the building having no heavy mass. Whereas, the bending moment increases with the introduction of heavy masses at different floors. Maximum increase in the value of bending moment of column was calculated as $15.7 \%, 15.8 \%$ and $15.8 \%$ approximately when the heavy mass was placed at $2^{\text {nd }}$ floor, $7^{\text {th }}$ floor and $13^{\text {th }}$ floor respectively when compared to the building having no heavy mass. See figure 16, 17, 18 and 19.

Table 3: Description of Displacement and Bending Moment in Column

\begin{tabular}{|c|c|c|}
\hline Floor & $\begin{array}{c}\text { Maximum decrease in the column } \\
\text { Displacement }\end{array}$ & $\begin{array}{c}\text { Maximum increase in the value of Bending moment of } \\
\text { column }\end{array}$ \\
\hline $2^{\text {th }}$ floor & $4 \%$ & $15.7 \%$ \\
\hline $7^{\text {th }}$ floor & $6 \%$ & $1.5 \%$ \\
\hline $13^{\text {th }}$ floor & $7 \%$ & $1.7 \%$ \\
\hline
\end{tabular}

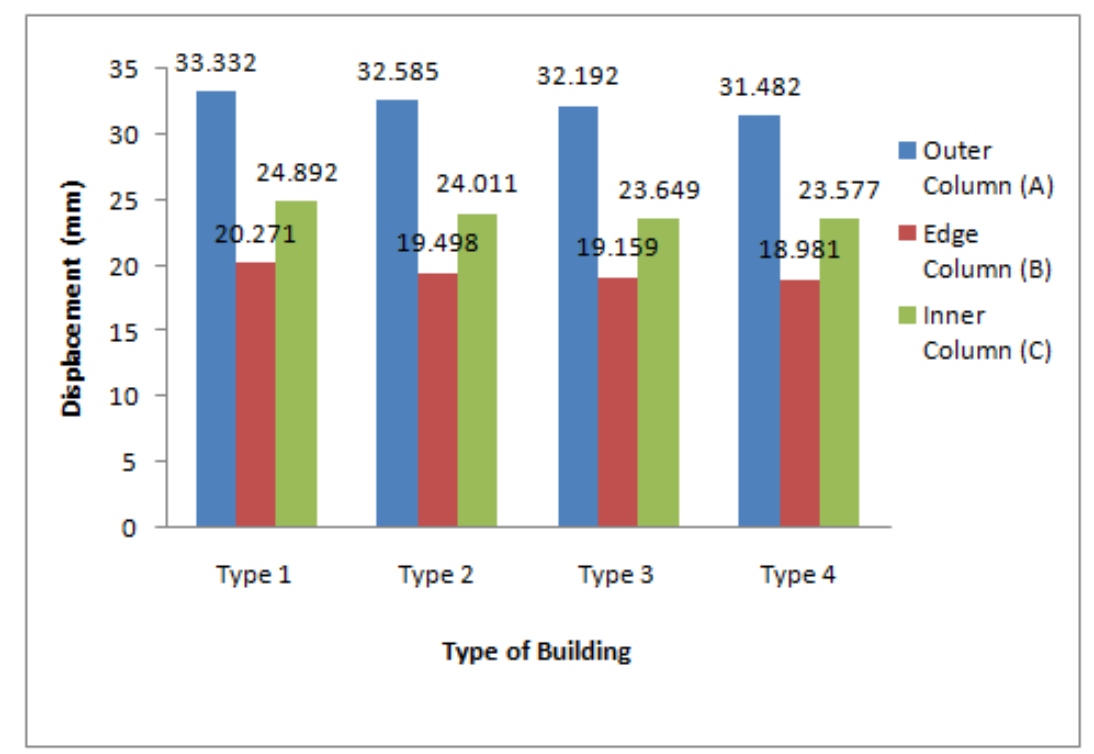

Figure 16: Maximum Displacement of Columns in 15 Storey Building. 


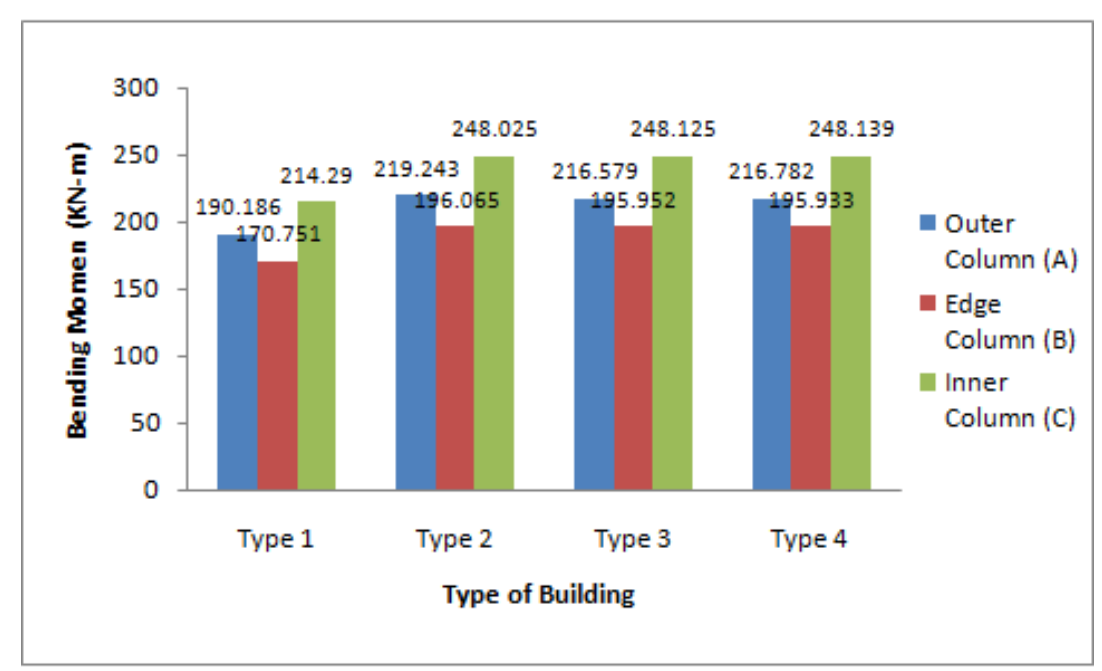

Figure 17: Maximum Bending in Columns (Kn-m) in 15 Storey Building.

As the cross-sectional properties were revised after adding the heavy mass, the total quantity of the building changes as shown in figure 22, 23, 24 and 25. Maximum steel quantity for type 1, type 2, type 3 and type 4 buildings is $20050 \mathrm{kN}, 20597 \mathrm{kN}, 20928 \mathrm{Kn}$ and $21156 \mathrm{Kn}$ respectively. The percentage increase in the quantity of building is $2.7 \%$, $4.4 \%$ and $5.5 \%$ in type 2 , type 3 and type 4 buildings.

Table 4: Description of Total Percentage Increase in Quantity

\begin{tabular}{|c|c|c|}
\hline Building Type & Total Quantity & Total Percentage Increase \\
\hline Type 1 & $20050 \mathrm{kN}$ & - \\
\hline Type 2 & $20597 \mathrm{kN}$ & $2.7 \%$ \\
\hline Type 3 & $20928 \mathrm{kN}$ & $4.4 \%$ \\
\hline Type 4 & $21156 \mathrm{kN}$ & $5.5 \%$ \\
\hline
\end{tabular}

\section{RESULTS OF 20 STOREY BUILDING}

The results of various parameters have been represented below:

The maximum bending moment in the $4^{\text {th }}$ floor beams with and without heavy mass was recorded as $299.86 \mathrm{kN}-\mathrm{m}$ and $262.37 \mathrm{kN}-\mathrm{m}$ respectively. But if the same mass is shifted to $10^{\text {th }}$ floor of the building, then the maximum bending moment in $10^{\text {th }}$ floor beams with and without the heavy mass becomes $311.99 \mathrm{kN}-\mathrm{m}$ and $272.309 \mathrm{kN}-\mathrm{m}$ respectively. Again after shifting the heavy mass onto the $16^{\text {th }}$ floor, the value of maximum bending moment in $16^{\text {th }}$ floor beams with and without the heavy mass comes out to be $286.956 \mathrm{kN}-\mathrm{m}$ and $241.944 \mathrm{kN}-\mathrm{m}$ respectively. Therefore, from figure 26,27 and 28 , it was concluded that when the heavy mass was placed at $4^{\text {th }}$ floor, the value of bending moment increases approximately $25 \%$ whereas, when the heavy mass is shifted to $10^{\text {th }}$ floor, the increase in bending moment was found out to be $35 \%$. And if the heavy mass is placed at $16^{\text {th }}$ floor, then the approximate increase in bending moment comes out to be $33 \%$. 


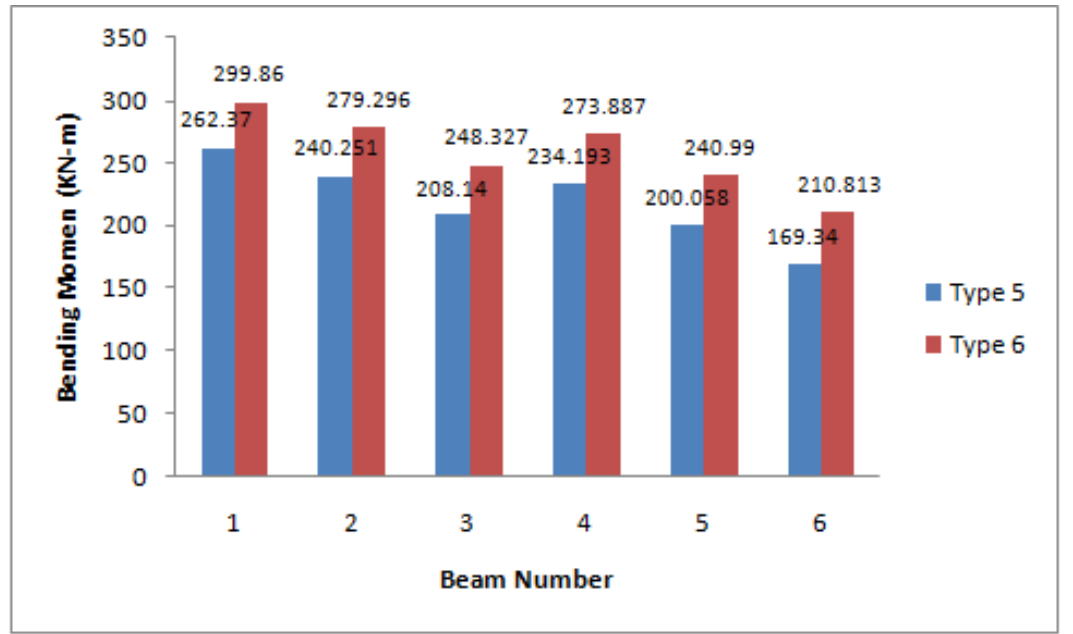

Figure 18: Bending Moment of $4^{\text {th }}$ Floor Beam with and without Heavy Mass of 20 Storey Building.

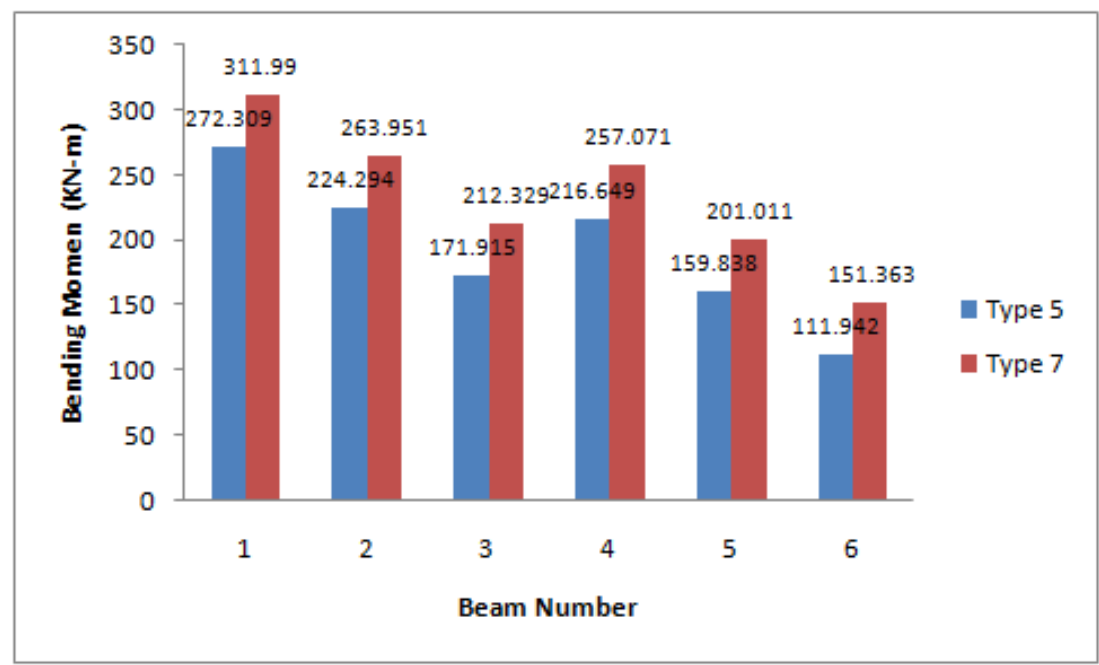

Figure 19: Bending Moment of $10^{\text {th }}$ Floor Beam with and without Heavy Mass of 20 Storey Building.

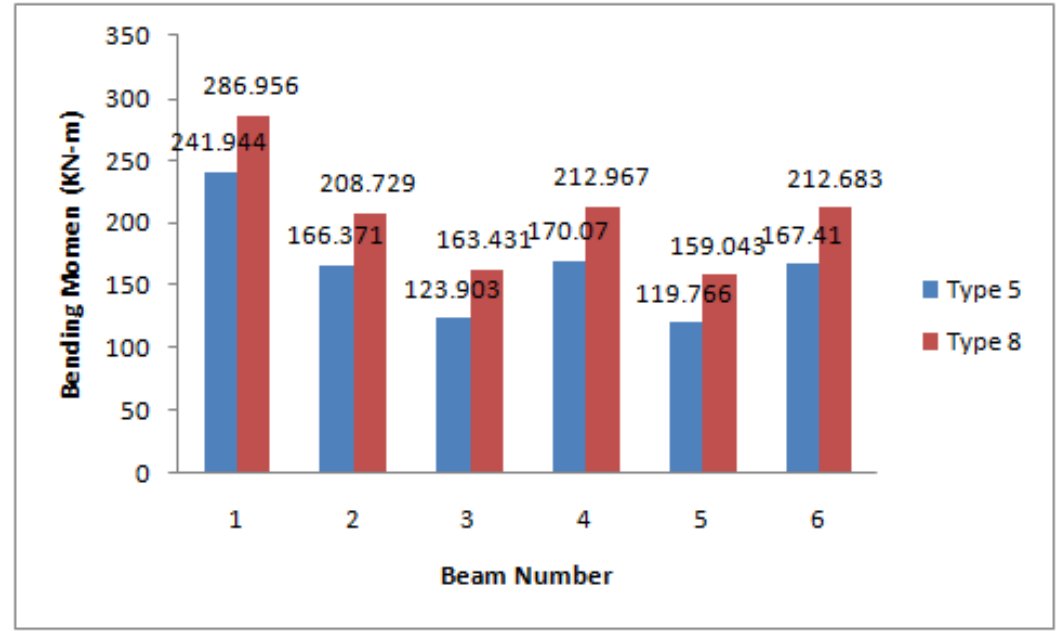

Figure 20: Bending Moment of $16^{\text {th }}$ Floor Beam with and without Heavy Mass of 20 Storey Building.

The maximum shear force in the $4^{\text {th }}$ floor beams with and without heavy mass was recorded as $180.289 \mathrm{kN}$ and $148.68 \mathrm{kN}$ respectively. But if the same mass is shifted to $10^{\text {th }}$ floor of the building, then the maximum shear force in $10^{\text {th }}$ floor beams with and without the heavy mass becomes $183.704 \mathrm{kN}$ and $151.356 \mathrm{kN}$ respectively. Again after shifting the 
heavy mass onto the $16^{\text {th }}$ floor, the value of maximum shear force in $16^{\text {th }}$ floor beams with and without the heavy mass comes out to be $174.993 \mathrm{kN}$ and $140.365 \mathrm{kN}$ respectively. Therefore, from figure 29, 30 and 31, it was concluded that when the heavy mass was placed at $4^{\text {th }}$ floor, the value of shear force increases approximately $28 \%$ whereas, when the heavy mass is shifted to $10^{\text {th }}$ floor, the increase in shear force was found out to be $33 \%$. And if the heavy mass is placed at $16^{\text {th }}$ floor, then the approximate increase in shear force comes out to be $32 \%$.

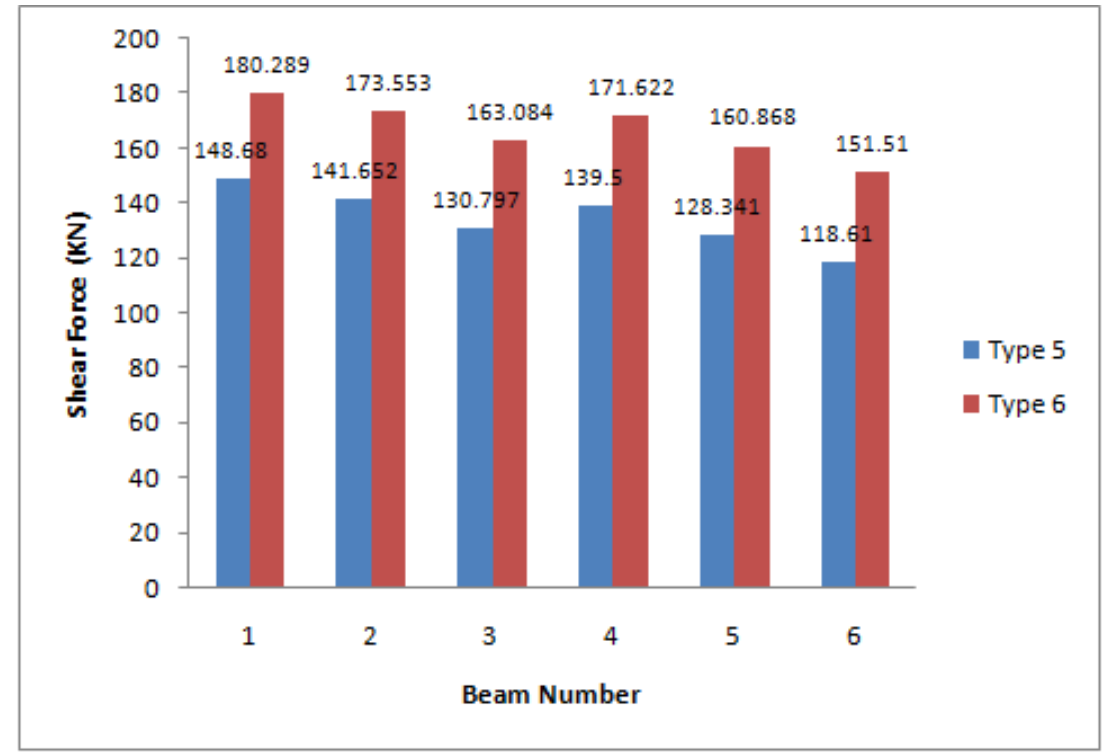

Figure 21: Shear Force of $4{ }^{\text {nd }}$ Floor Beam with and without Heavy Mass of 20 Storey Building.

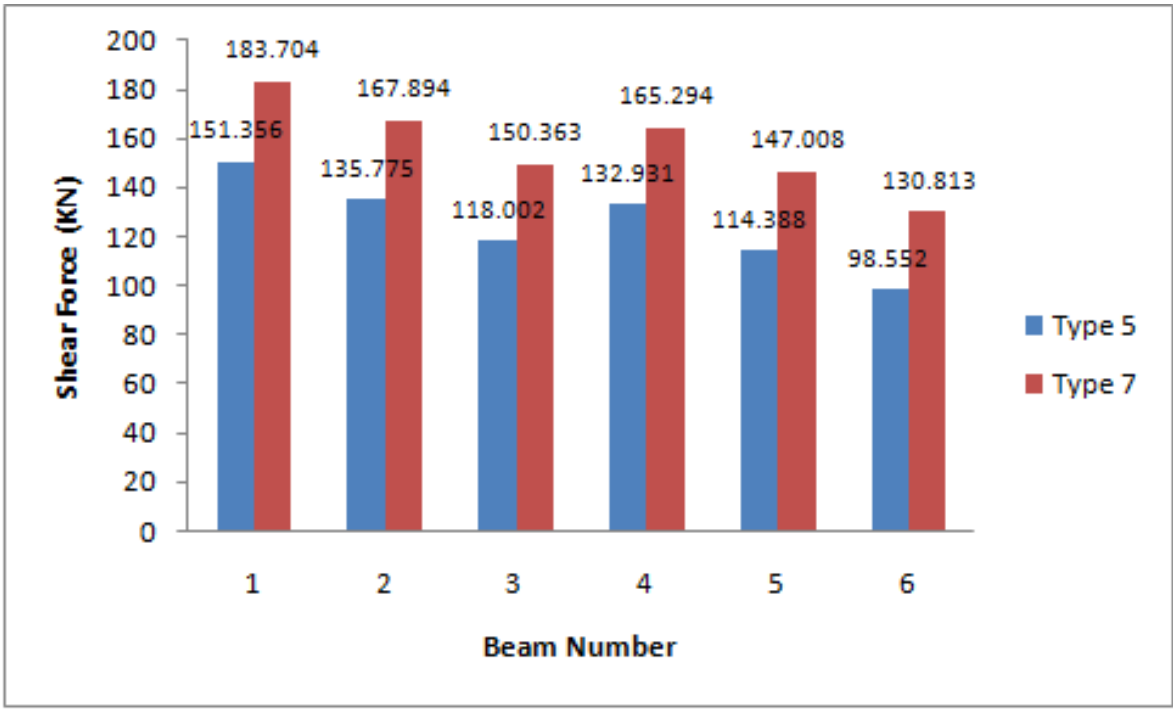

Figure 22: Shear Force of $10^{\text {th }}$ Floor Beam with and without Heavy Mass of 20 Storey Building. 


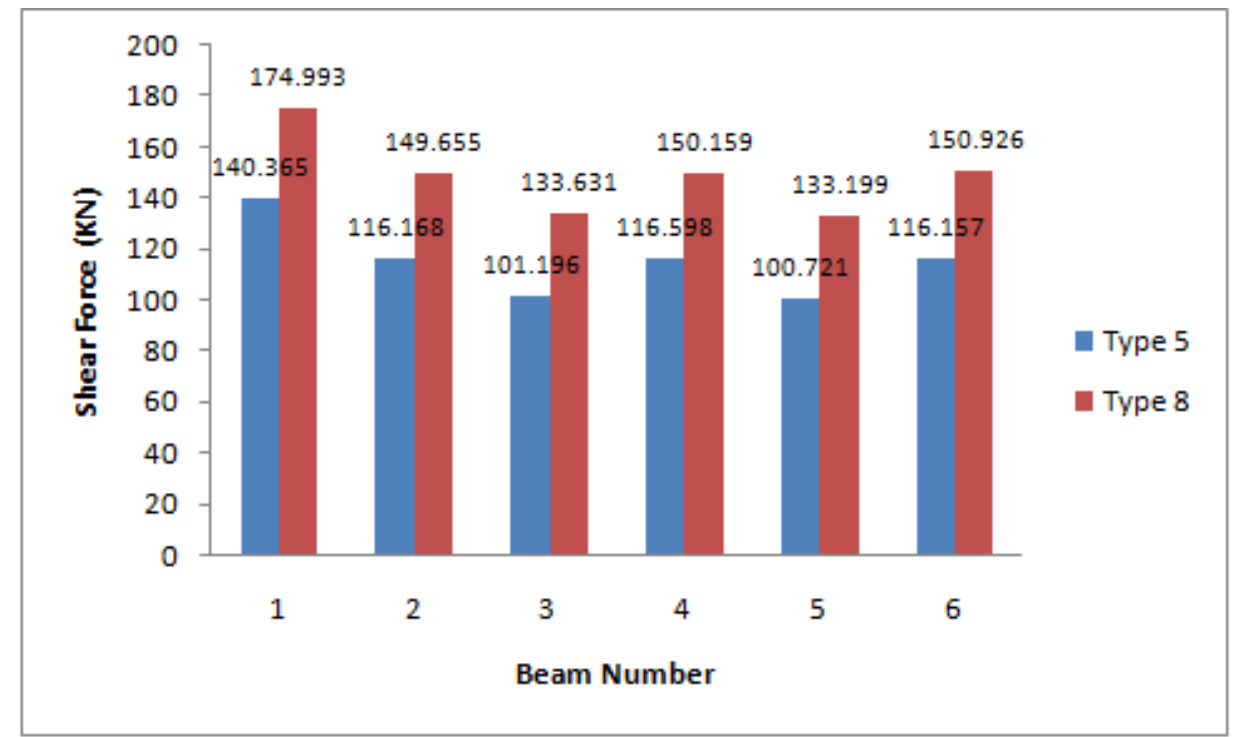

Figure 23: Shear Force of $16^{\text {th }}$ Floor Beam with and without Heavy Mass of 20 Storey Building.

As the beam beneath the floating column act as a cantilever beam, the bending moment and shear force value comes out to be huge. Maximum bending moment and shear force value comes out to be $441.011 \mathrm{kN}-\mathrm{m}$ and $202.942 \mathrm{kN}$ repectively. See figure 32 and 33.

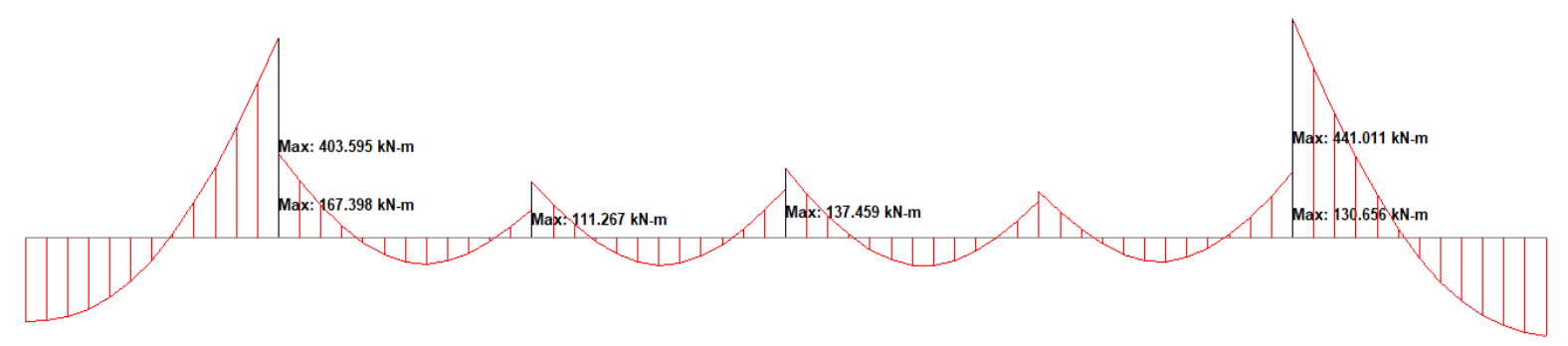

Figure 24: Bending Moment of End Beams where Floating Columns are Placed.

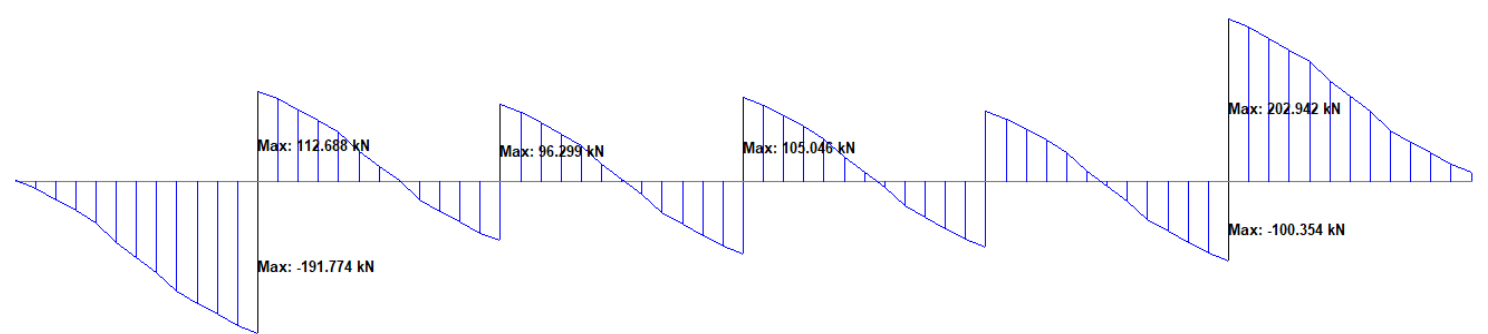

Figure 25: Shear Force of End Beams where Floating Columns are Placed.

Due to increase in the total weight of the building (having heavy mass) which increases the lateral stability, the displacement of the columns decreases as shown in figure 34, 35, 36 and 37. Maximum decrease in the column displacement was calculated as $0.4 \%, 1.2 \%$ and $2.6 \%$ approximately when the heavy mass was placed at $4^{\text {th }}$ floor, $10^{\text {th }}$ floor and $16^{\text {th }}$ floor respectively when compared to the building having no heavy mass. Whereas, the bending moment increases with the introduction of heavy masses at different floors. Maximum increase in the value of bending moment of 
column was calculated as $2.1 \%, 1.5 \%$ and $1.7 \%$ approximately when the heavy mass was placed at $4^{\text {th }}$ floor, $10^{\text {th }}$ floor and $16^{\text {th }}$ floor respectively when compared to the building having no heavy mass.

Table 5: Description of Displacement and Bending Moment in Column

\begin{tabular}{|c|c|c|}
\hline Floor & $\begin{array}{c}\text { Maximum decrease in the column } \\
\text { displacement }\end{array}$ & $\begin{array}{c}\text { Maximum increase in the value of bending moment of } \\
\text { column }\end{array}$ \\
\hline $4^{\text {th }}$ floor & $0.4 \%$ & $2.1 \%$ \\
\hline $10^{\text {th }}$ floor & $1.2 \%$ & $1.5 \%$ \\
\hline $16^{\text {th }}$ floor & $2.6 \%$ & $1.7 \%$ \\
\hline
\end{tabular}

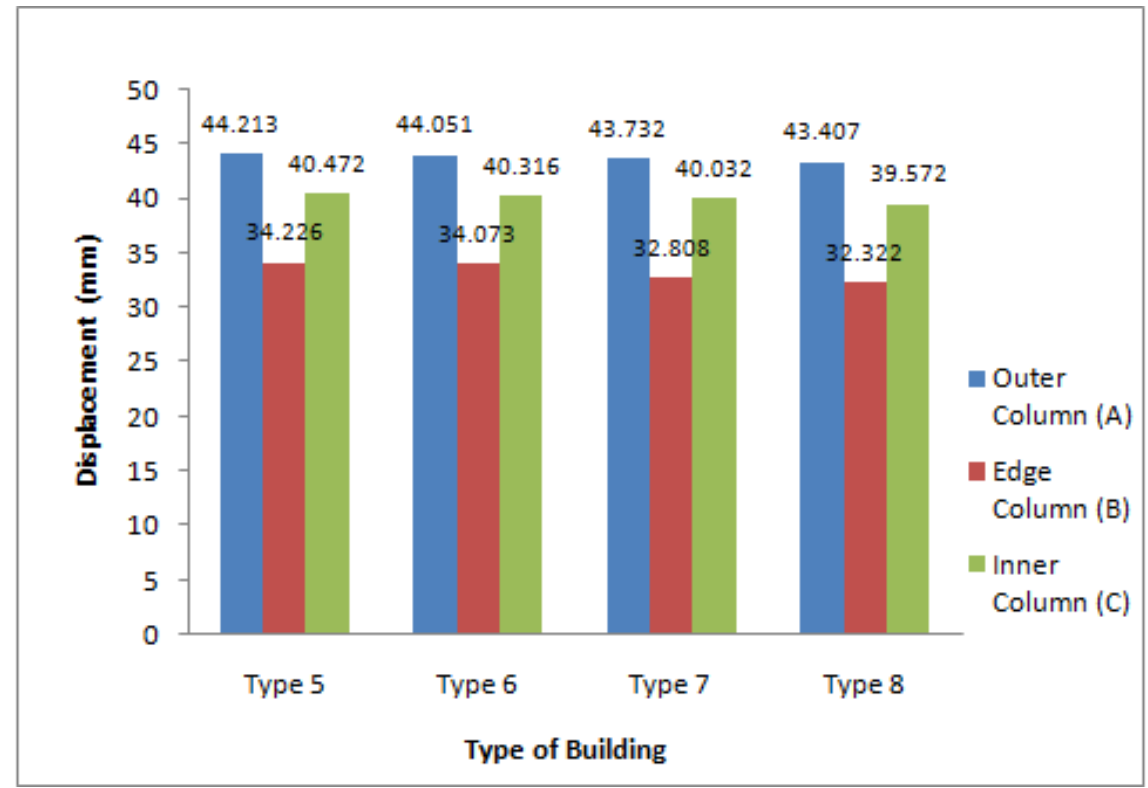

Figure 26: Maximum Displacement of Columns in 20 Storey Building.

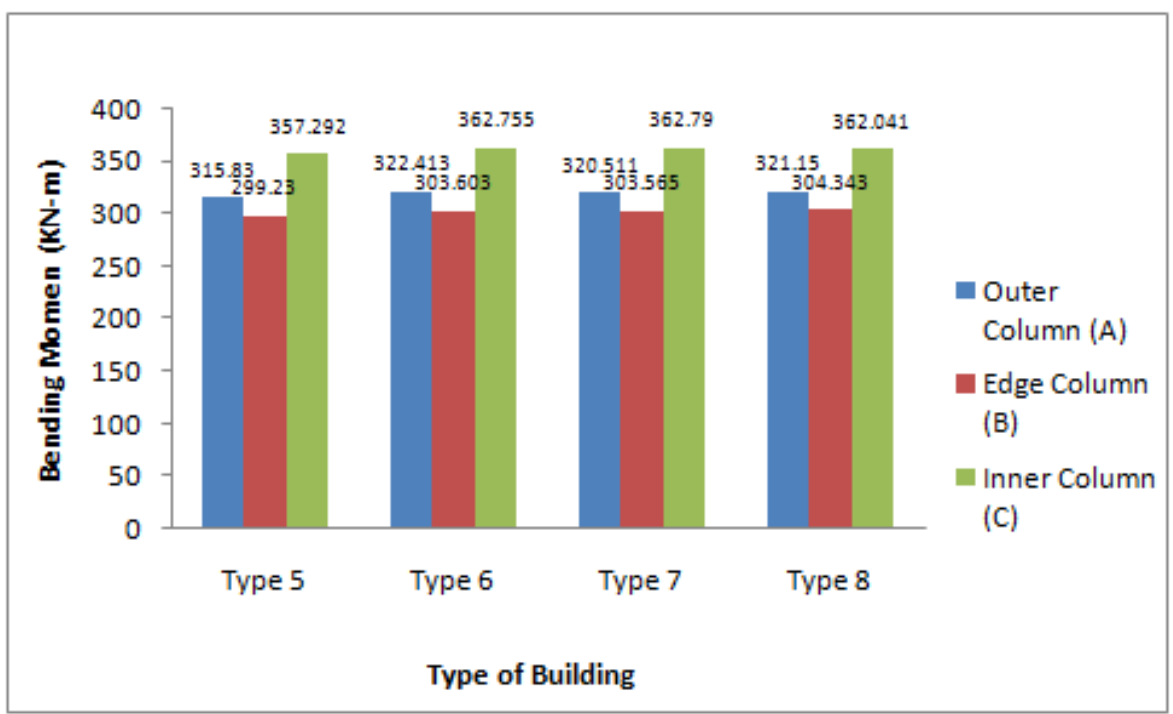

Figure 27: Maximum Bending in Columns (kN-m) in 15 Storey Building.

As the cross-sectional properties were revised after adding the heavy mass, the total quantity of the building changes. Maximum steel quantity for type 5, type 6, type 7 and type 8 buildings is $29137 \mathrm{kN}, 29360 \mathrm{kN}, 29691 \mathrm{kN}$ and $30040 \mathrm{kN}$ respectively. The percentage increase in the quantity of building is $0.8 \%, 1.9 \%$ and $3.10 \%$ in type 6 , type 7 and type 8 buildings. 
Table 6: Description of Total Percentage Increase in Quantity

\begin{tabular}{|c|c|c|}
\hline Building Type & Total Quantity & Total Percentage Increase \\
\hline Type 5 & $29137 \mathrm{kN}$ & - \\
\hline Type 6 & $29360 \mathrm{kN}$ & $0.8 \%$ \\
\hline Type 7 & $29691 \mathrm{kN}$ & $1.9 \%$ \\
\hline Type 8 & $30040 \mathrm{kN}$ & $3.10 \%$ \\
\hline
\end{tabular}

\section{CONCLUSIONS}

The comparison work between these aforementioned building were carried out and the final conclusions were drawn from the results of 15 storey buildings. They are as follows:

- When the heavy mass was placed at $2^{\text {nd }}$ floor, the value of bending moment increases approximately $26 \%$ whereas, when the heavy mass is shifted to $7^{\text {th }}$ floor, the increase in bending moment was found out to be $31 \%$. And if the heavy mass is placed at $13^{\text {th }}$ floor, then the approximate increase in bending moment comes out to be $36 \%$.

- When the heavy mass was placed at $2^{\text {nd }}$ floor, the value of shear force increases approximately $29 \%$ whereas, when the heavy mass is shifted to $7^{\text {th }}$ floor, the increase in shear force was found out to be $31 \%$. And if the heavy mass is placed at $13^{\text {th }}$ floor, then the approximate increase in shear force comes out to be $34 \%$.

- As the beam beneath the floating column act as a cantilever beam, the bending moment and shear force value comes out to be huge. Maximum bending moment and shear force value comes out to be $454 \mathrm{kN}-\mathrm{m}$ and $207 \mathrm{kN}$ repectively.

- Due to increase in the total weight of the building (having heavy mass) which increases the lateral stability, the displacement of the columns decreases. Maximum decrease in the column displacement was calculated as 4\%, $6 \%$ and $7 \%$ approximately when the heavy mass was placed at $2^{\text {nd }}$ floor, $7^{\text {th }}$ floor and $13^{\text {th }}$ floor respectively when compared to the building having no heavy mass. Whereas, the bending moment increases with the introduction of heavy masses at different floors. Maximum increase in the value of bending moment of column was calculated as $15.7 \%, 15.8 \%$ and $15.8 \%$ approximately when the heavy mass was placed at $2^{\text {nd }}$ floor, $7^{\text {th }}$ floor and $13^{\text {th }}$ floor respectively when compared to the building having no heavy mass.

- As the cross-sectional properties were revised after adding the heavy mass, the total quantity of the building changes. Maximum steel quantity for type 1, type 2, type 3 and type 4 buildings is $20050 \mathrm{kN}, 20597 \mathrm{kN}, 20928 \mathrm{kN}$ and $21156 \mathrm{kN}$ respectively. The percentage increase in the quantity of building is $2.7 \%, 4.4 \%$ and $5.5 \%$ in type 2 , type 3 and type 4 buildings.

The comparison work between these aforementioned building were carried out and the final conclusions were drawn from the results of 20storey buildings. They are as follows:

- When the heavy mass was placed at $4^{\text {th }}$ floor, the value of bending moment increases approximately $25 \%$ whereas, when the heavy mass is shifted to $10^{\text {th }}$ floor, the increase in bending moment was found out to be $35 \%$. And if the heavy mass is placed at $16^{\text {th }}$ floor, then the approximate increase in bending moment comes out to be $33 \%$. 
- When the heavy mass was placed at $4^{\text {th }}$ floor, the value of shear force increases approximately $28 \%$ whereas, when the heavy mass is shifted to $10^{\text {th }}$ floor, the increase in shear force was found out to be $33 \%$. And if the heavy mass is placed at $16^{\text {th }}$ floor, then the approximate increase in shear force comes out to be $32 \%$.

- As the beam beneath the floating column act as a cantilever beam, the bending moment and shear force value comes out to be huge. Maximum bending moment and shear force value comes out to be $441.011 \mathrm{kN}-\mathrm{m}$ and $202.942 \mathrm{kN}$ repectively.

- Due to increase in the total weight of the building (having heavy mass) which increases the lateral stability, the displacement of the columns decreases. Maximum decrease in the column displacement was calculated as $0.4 \%$, $1.2 \%$ and $2.6 \%$ approximately when the heavy mass was placed at $4^{\text {th }}$ floor, $10^{\text {th }}$ floor and $16^{\text {th }}$ floor respectively when compared to the building having no heavy mass. Whereas, the bending moment increases with the introduction of heavy masses at different floors. Maximum increase in the value of bending moment of column was calculated as $2.1 \%, 1.5 \%$ and $1.7 \%$ approximately when the heavy mass was placed at $4^{\text {th }}$ floor, $10^{\text {th }}$ floor and $16^{\text {th }}$ floor respectively when compared to the building having no heavy mass.

- As the cross-sectional properties were revised after adding the heavy mass, the total quantity of the building changes. Maximum steel quantity for type 5, type 6, type 7 and type 8 buildings is $29137 \mathrm{kN}, 29360 \mathrm{kN}, 29691 \mathrm{Kn}$ and $30040 \mathrm{kN}$ respectively. The percentage increase in the quantity of building is $0.8 \%, 1.9 \%$ and $3.10 \%$ in type 6 , type 7 and type 8 buildings.

\section{REFERENCES}

1. Sourabh Dhiman, et al. (2019) A Research on the Behaviour of Columns of Steel Framed Structure with Various Steel Sections, International Journal of Innovative Technology and Exploring Engineering, Volume-8 Issue-8, pp-1382-1386.

2. Ailin Zhanga, et al.(2019) Performance study of self-centering steel frame with intermediate columns containing friction dampers, ELSEVIER, https://doi.org/10.1016/j.engstruct.2019.02.023, pp-382-398.

3. Raffaele Landolfo, (2019) Lightweight steel framed systems in seismic areas: Current achievements and future challenges, ELSEVIER, https://doi.org/10.1016/j.tws.2019.03.039, pp-114-131.

4. Sharma, Ashwani, and Murtaza MA. "Modeling and Finite Element Analysis of Vertical Axis Wind Turbine Rotor Configurations." International Journal of Mechanical and Production Engineering Research and Development (IJMPERD) ISSN (P) (2016): 2249-6890.

5. ResatOyguc,et al. (2018) Seismic behavior of irregular reinforced-concrete structures under multiple earthquake excitations, ELSEVIER, http://dx.doi.org/10.1016/j.soildyn.2017.10.002, pp-15-32.

6. George A. Papagiannopoulos, (2018) On the seismic behaviour of tension-only concentrically braced steel structures, ELSEVIER, https://doi.org/10.1016/j.soildyn.2018.08.017, pp-27-35.

7. Senthil, Ramalingam., Mukund. Gupta, and Chinmaya. Rath. "Parametric analysis of a concentrated solar receiver with Scheffler reflector." International Journal of Mechanical and Production Engineering Research and Development 7.5 (2017): 261-268.

8. Jing He, et al.(2018) Finite-element modeling framework for predicting realistic responses of light-frame low-rise buildings under wind loads, ELSEVIER, https://doi.org/10.1016/j.engstruct.2018.01.034, pp-53-69. 
9. Ankur Tailor, et al.(2017) Comparative Performance Evaluation of Steel Column Building \& Concrete Filled Tube Column Building under Static and Dynamic Loading, ELSEVIER, doi: 10.1016/j.proeng.2016.12.233, pp- 1847 - 1853.

10. S. Bhosale, et al.(2017) Vertical Irregularity of Buildings: Regularity Index versus Seismic Risk, American Society of Civil Engineers, DOI: 10.1061/AJRUA6.0000900, pp- 1-10.

11. DiaEddinNassania, et al.(2017) Comparative Response Assessment of Steel Frames With Different Bracing Systems Under Seismic Effect, ELSEVIER, http://dx.doi.org/10.1016/j.istruc.2017.06.006, pp- 229-242.

12. Sang Whan Han, et al.(2017) Seismic collapse performance of special moment steel frames with torsional irregularities, ELSEVIER, http://dx.doi.org/10.1016/j.engstruct.2017.03.045, pp-482-494.

13. E. Brunesi, et al.(2016) Seismic analysis of high-rise mega-braced frame-core buildings, ELSEVIER, http://dx.doi.org/10.1016/j.engstruct. 2016.02.019, pp-1-17.

14. Prasad, U. Shiva, et al. "Design and analysis of two throat wind tunnel." International Journal of Mechanical and Production Engineering Research and Development 7.4 (2017): 381-388.

15. Ali Kocak, et al.(2015) Performance Assessment of Irregular RC Buildings With Shear Walls After Earthquake, Engineering Failure Analysis, http://dx.doi.org/10.1016/j.engfailanal.2015.05.016.

16. George Georgoussis, et al.(2015) Approximate seismic analysis of multi-story buildings with mass and stiffness irregularities, ELSEVIER, doi: 10.1016/j.proeng.2015.11.147, pp- 959 - 966.

17. Ikeh, C. U., and C. M. Ugbaja. "Comparative study of the efficiency of storage batteries (Indian and Chinese Technology) used for solar security lighting application in Anambra State, Nigeria." International Journal of Research in Applied, Natural and Social Sciences 6.8 (2018): 53-60.

18. A. Sattainathan Sharma, et al.(2015) Comparative study of cost and time evaluation in RCC, steel \& Composite high rise building, Journal of Chemical and Pharmaceutical Sciences, Volume 8 Issue 4, pp- 911-915.

19. Qiang Sun, et al.(2014) Study on mechanical characteristics and safety evaluation method of steel frame structure after fire, Theoretical \& Applied Mechanics, doi:10.1063/2.1403406, pp- 1 - 6.

20. Mr. S. Mahesh, et al.(2014), Comparison of analysis and design of regular and irregular configuration of multi Story building in various seismic zones and various types of soils using ETABS and STAAD, IOSR Journal of Mechanical and Civil Engineering, Volume 11, Issue 6, pp 45-52.

21. Prerna Nautiyal, et al.(2014), Seismic Response Evaluation of RC frame building with Floating Column considering different Soil Conditions, International Journal of Current Engineering and Technology, Vol.4, No.1, pp 132- 138. Ketan Patel, Sonal Thakkar, (2013) Analysis of CFT, RCC And Steel Building Subjected To Lateral Loading, ELSEVIER, doi: 10.1016/j.proeng.2013.01.035, pp- $259-265$.

22. P.M.B. Raj KiranNanduri, et al.(2013) Optimum Position of Outrigger System for High-Rise Reinforced Concrete Buildings Under Wind And Earthquake Loadings, American Journal of Engineering Research, Volume-02, Issue-08, pp-76-89.

23. Hendramawat A Safarizki, et al.(2013) Evaluation of the Use of Steel Bracing to Improve Seismic Performance of Reinforced Concrete Building, ELSEVIER, doi: 10.1016/j.proeng.2013.03.040, pp-447 - 456.

24. IS: 800:2007- General Construction in Steel - Code for Practice

25. IS 875 (Part 1):1987- Code of Practice for Design Loads (Other Than Earthquake) For Buildings and Structures: Deal Load 
26. IS 875 (Part 2):1987- Code of Practice for Design Loads (Other Than Earthquake) For Buildings and Structures: Imposed Load

27. IS 875 (Part 3):1987- Code of Practice for Design Loads (Other Than Earthquake) For Buildings and Structures: Wind Load. 